\title{
Adsorption isotherm and thermodynamic studies of As(III) removal from aqueous solutions using used cigarette filter ash
}

\author{
Pezhman Zein Al-Salehin ${ }^{1} \cdot$ Farid Moeinpour ${ }^{2}\left(\right.$ F $^{\circ}$ Fatemeh S. Mohseni-Shahri ${ }^{2}$
}

Received: 2 August 2019 / Accepted: 1 October 2019 / Published online: 14 October 2019

(c) The Author(s) 2019

\begin{abstract}
In the present paper, used cigarette filter ash was prepared and used as an active adsorbent to remove As(III) ions from aqueous solutions. The prepared adsorbent structure was identified by scanning electron microscopy analysis, BrunauerEmmett-Teller method and energy-dispersive X-ray spectroscopy analysis. The influence of contact time, $\mathrm{pH}$, adsorbent dose and initial concentration of As(III) on the removal of As(III) was assessed. Several isotherm models were checked to illustrate the adsorption equilibrium. The adsorption equilibrium data adapted well with the Langmuir isotherm model. The maximum adsorption capacity of $33.33 \mathrm{mg} / \mathrm{g}$ was acquired from the Langmuir isotherm. The calculated thermodynamic variables verified that the adsorption process is spontaneous and endothermic.
\end{abstract}

Keywords Used cigarette filter ash $\cdot$ As(III) $\cdot$ Adsorption $\cdot$ Thermodynamics

\section{Introduction}

Heavy metals are high stable elements with bioaccumulation potential in the food chain. These metals do not have a task in the body and therefore cause toxic effects. Due to the development of industrial activities, an increase in the amount of heavy metals in river flows has resulted in the production of high levels of cadmium, mercury, nickel, lead and arsenic that have a high impact on water toxicity (Wang et al. 2011). Heavy metals, even at low concentrations, are poisonous, carcinogenic or mutagenic. Therefore, they are a major concern of the international community (Mishra et al. 2019). Pollution of water resources into heavy metals such as arsenic and contact with them lead to harmful effects on human health, such as kidney damage and high blood pressure (Huang et al. 2013). Arsenic is a natural metal that is often obtained from

Electronic supplementary material The online version of this article (https://doi.org/10.1007/s13201-019-1059-9) contains supplementary material, which is available to authorized users.

Farid Moeinpour

fmoeinpour@iauba.ac.ir; f.moeinpour@gmail.com

1 Department of Water and Wastewater Engineering, Bandar Abbas Branch, Islamic Azad University, Bandar Abbas, Iran

2 Department of Chemistry, Bandar Abbas Branch, Islamic Azad University, Bandar Abbas 7915893144, Iran the Earth's crust (Bhowmick et al. 2014). The presence of arsenic in water resources is due to leakage from rocks and sediments and volcanic materials (Rahmani et al. 2011). Human activities, such as melting of metals, the use of pesticides, glass and ceramics manufacturing, release arsenic into the environment and water resources ( $\mathrm{Li}$ et al. 2019). Arsenite $\left(\mathrm{AsO}_{3}^{3-}\right)$ and arsenate $\left(\mathrm{AsO}_{4}^{3-}\right)$ are among the arsenic species found in water resources, especially groundwaters (Bhowmick et al. 2014). Arsenite is more toxic than arsenate. Considering such hazardous effects of arsenic on human health, there is a critical demand for investigating low-cost methods for arsenic removal (Song et al. 2015). Recently, due to economic considerations, research into inexpensive and efficient methods for wastewater treatment has been considered. Ash is a good alternative to activated carbon due to its low cost of production as well as the simplicity of the process (Vázquez-Rivera et al. 2015; Haddabi et al. 2016). Ashes can be produced from a lot of carbonaceous materials, such as wood, peanuts and fruit stones (Moayedi et al. 2019). Discarded cigarette filters are known to be one of the largest solid waste in the world (Smith and Novotny 2011). They significantly contaminate the environment. The used cigarette filters are hazardous and toxic waste (Barnes 2011). They are found almost everywhere, especially on sidewalks and beaches. They are dangerous when they find a way to enter water resources such as rivers and seas (Novotny et al. 2009). Almost most of the cigarette filters are made of cellulose acetate fiber, which is a plastic material. 
These fibers include titanium dioxide and glycerol triacetate as plasticizer (Smith et al. 2015). Here, we introduce the used cigarette filter ash as an effective adsorbent. The adsorption behavior of arsenic(III) on the surface of this new adsorbent has been studied in detail.

\section{Materials and methods}

\section{General}

All of the materials used in the present paper have been on an analytical scale. In this study, $\mathrm{As}_{2} \mathrm{O}_{3}$ salt (Merck, Germany) was used to make an arsenic stock solution. Nitric acid and sodium hydroxide $0.1 \mathrm{~mol} / \mathrm{L}$ were used to adjust the $\mathrm{pH}$.

\section{Preparation of used cigarette filters ash}

First, the papers around the used cigarette filters were removed. Then, the filters were washed and dried in an oven at $80{ }^{\circ} \mathrm{C}$ for $24 \mathrm{~h}$ and were heated in an electrical furnace at $900^{\circ} \mathrm{C}$ for $2 \mathrm{~h}$. The method is similar to other researches that have been done (Lee et al. 2014; Soltani et al. 2014).

\section{Adsorption experiments}

Adsorption of As(III) ions on used cigarette filters ash was investigated under discontinuous conditions. All tests were done in a $100-\mathrm{mL}$ Erlenmeyer flask containing specific amounts of adsorbent and initial concentration of As(III) ions, at different times. By diluting the stock As(III) solution $(1000 \mathrm{mg} / \mathrm{L})$, solutions were obtained with the desired concentrations. In order to optimize the test conditions, the effect of $\mathrm{pH}$ on the adsorption process was studied in the range of $2-9$. The initial concentrations for lead were $5-100 \mathrm{mg} / \mathrm{L}$, the contact times were 3-60 min, and the adsorbent doses were $0.01-0.9 \mathrm{~g}$. The prepared solutions were mixed at a constant speed of $200 \mathrm{rpm}$ and the time set for each test. After the mentioned time, the solutions reached the equilibrium; at the next step, the used cigarette filters ash was separated from the solution by simple filtration. Then, the residual concentrations of As(III) were measured in the solution by atomic absorption spectroscopy (AAS). The adsorption efficiency (\% removal) and adsorption capacity $\left(q_{\mathrm{e}}, \mathrm{mg} / \mathrm{g}\right)$ could be calculated from the subsequent equations:

$\%$ Removal $=\frac{C_{0}-C_{\mathrm{e}}}{C_{0}} \times 100$

$q_{\mathrm{e}}=\frac{\left(C_{0}-C_{\mathrm{e}}\right) V}{m}$, where $q_{\mathrm{e}}$ is the equilibrium adsorption capacity $(\mathrm{mg} / \mathrm{g}) . C_{0}$ and $C_{\mathrm{e}}$ are the initial and equilibrium concentrations $(\mathrm{mg} / \mathrm{L})$ of $\mathrm{As}(\mathrm{III})$ in the solution, respectively. $V$ and $m$ are the volume of solution (L) and mass of adsorbent ( $\mathrm{g}$ ), respectively.

\section{Adsorption isotherms}

Adsorption isotherms were obtained by using $0.10 \mathrm{~g}$ of adsorbent and $100 \mathrm{~mL}$ of As(III) solution with different concentrations $(5-100 \mathrm{mg} / \mathrm{L})$ at $298 \mathrm{~K}$. These solutions were buffered at an optimum $\mathrm{pH}(\mathrm{pH}=6)$ for adsorption and agitated on a shaker at $200 \mathrm{rpm}$ until they reached adsorption equilibrium (10 min). The quantity of As(III) adsorbed was derived from the concentration change. After that, various parameters of the isothermal study were analyzed.

\section{Adsorption thermodynamics}

Thermodynamic studies were performed by investigating the effect of temperature $\left(20-55^{\circ} \mathrm{C}\right)$ at an optimum adsorbent dose $(0.1 \mathrm{~g})$ and initial concentrations of As(III) $(10 \mathrm{mg} / \mathrm{L})$.

\section{Characterization}

Surface morphology and particle size were investigated by a Hitachi S-4800 SEM instrument. The surface areas and the pore size distribution were analyzed using the Brunauer-Emmett-Teller (BET) method by a Micromeritics apparatus (Gemini 2375) by adsorption of nitrogen at $77 \mathrm{~K}$. Adsorbent composition was determined using energy-dispersive X-ray spectroscopy (EDX) by an energy-dispersive X-ray XL30 Philips microscope.

\section{Results and discussion}

\section{Characterization of adsorbent}

The morphology of used cigarette filter ash was investigated using SEM analysis, as shown in Fig. 1. By examining this image, it can be said that the average diameter of these particles is around $10 \mu \mathrm{m}$. The adsorbent has a porous surface and numerous cavities. This porous surface provides access of As(III) ions to internal adsorbent surfaces. To further confirm the used cigarette filter ash composition, EDX spectrum was investigated (Fig. 2). Correlated signal peaks were found on the surface of the adsorbent sample. As expected, the main elements found in the used cigarette filter ash were carbon and titanium which correspond to the chemical composition of cigarette filters (Smith et al. 2015).

Some properties of the used filter cigarette ash are presented in Table 1. The used filter cigarette ash has a surface 


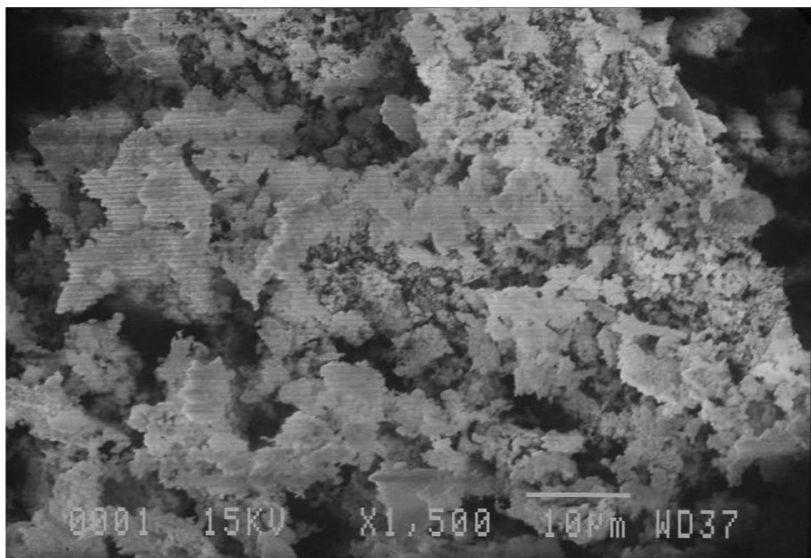

Fig. 1 SEM image of the used cigarette filter ash

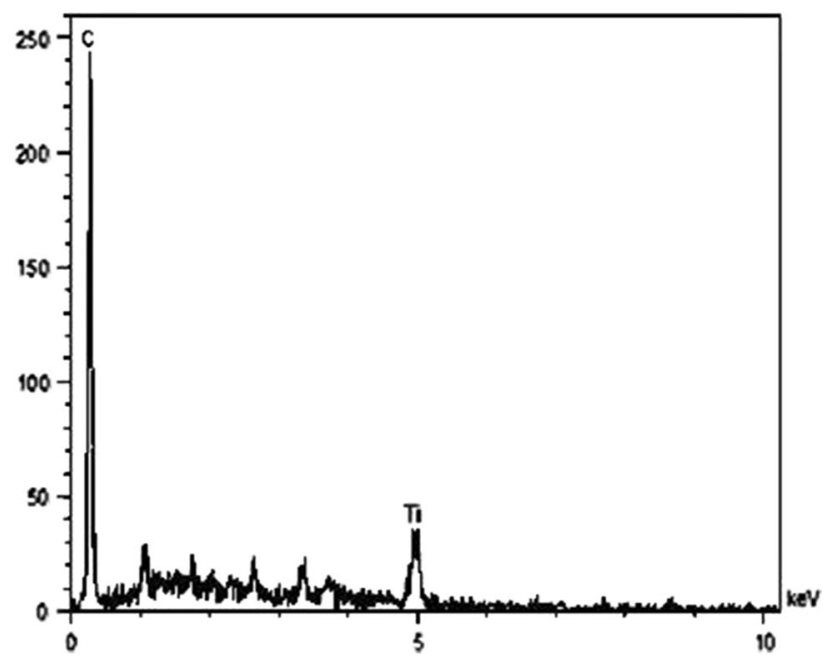

Fig. 2 EDX spectrum of the used cigarette filter ash

Table 1 Some properties of the used cigarette filter ash

\begin{tabular}{ll}
\hline Parameter & Value \\
\hline Specific surface area $\left(\mathrm{m}^{2} / \mathrm{g}\right)$ & 37.982 \\
Porous volume $\left(\mathrm{cm}^{3} / \mathrm{g}\right)$ & 0.743 \\
Water content $(\%)$ & Trace \\
\hline
\end{tabular}

area of about $37.982 \mathrm{~m}^{2} / \mathrm{g}$ and a porous volume equal to $0.743 \mathrm{~cm}^{3} / \mathrm{g}$.

\section{Determination of $\mathrm{pH}_{\mathrm{zpc}}$}

To determine $\mathrm{pH}_{\mathrm{zpc}}$, distilled water solutions were prepared with a pH between 2 and 12 using $\mathrm{HCl}$ and $\mathrm{NaOH}$ ( 1 and $0.1 \mathrm{~mol} / \mathrm{L}$ ). Then, $50 \mathrm{mg}$ of used cigarette filter ash was added to $50 \mathrm{ml}$ of solution. After $24 \mathrm{~h}$, the $\mathrm{pH}$ of the

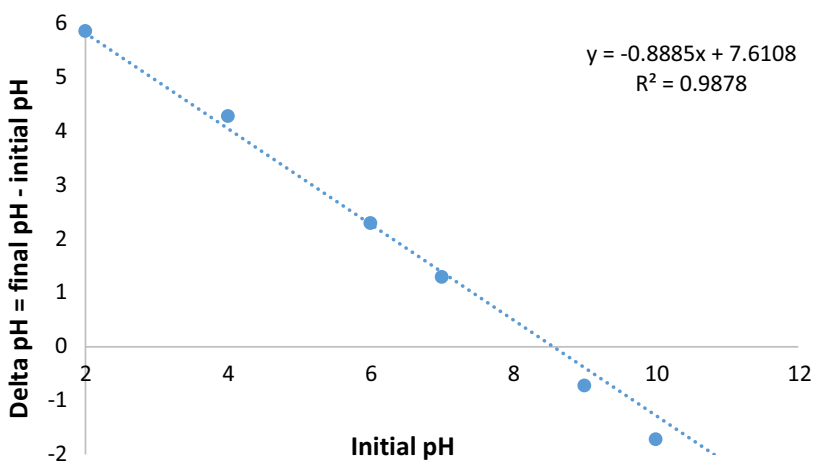

Fig. $3 \mathrm{pH}_{\mathrm{zpc}}$ determination of the used cigarette filter ash

solution was read. As shown in Fig. 3, $\mathrm{pH}_{\mathrm{zpc}}$ for the used cigarette filter ash is approximately 8.57.

\section{Effect of contact time variations on As(III) adsorption}

The study of the effect of contact time on the removal efficiency of As(III) indicated that As(III) adsorption involves two steps. The first step is the rapid adsorption, and the second step is the slower adsorption process that finally reaches the equilibrium conditions. The high rate of As(III) removal in the first step of the process can be attributed to the presence of active adsorption sites on the used filter cigarette ash surface. However, the number of such active sites decreases gradually with increasing contact time and increasing As(III) ions on the adsorbent surface, so that the speed of removal is noticeably reduced and the second stage begins. It should also be noted that the active adsorbent sites are located on the surface as well as the deeper part of the adsorbent. Therefore, at the onset of the adsorption process, all sites are able to participate in the adsorption process, but the surface sites are easily exposed to As(III) ions and are more likely to interact with them. As shown in Fig. 4, the maximum removal occurs within the first $10 \mathrm{~min}$ of the adsorption process and then there was no noticeable increase in removal efficiency. As the surface sites are saturated, the adsorption continues through the inner parts, which will slow down the adsorption process. Of course, this does not mean that at the beginning of the reaction, the adsorbent internal parts are not involved in the adsorption process. In fact, all sites contribute to As(III) uptake, but the rate of uptake in the early stages is controlled by adsorbent surface sites (Ngah and Hanafiah 2008). Based on the above results, the optimum contact time was determined $10 \mathrm{~min}$ (with $97.3 \%$ removal efficiency). 


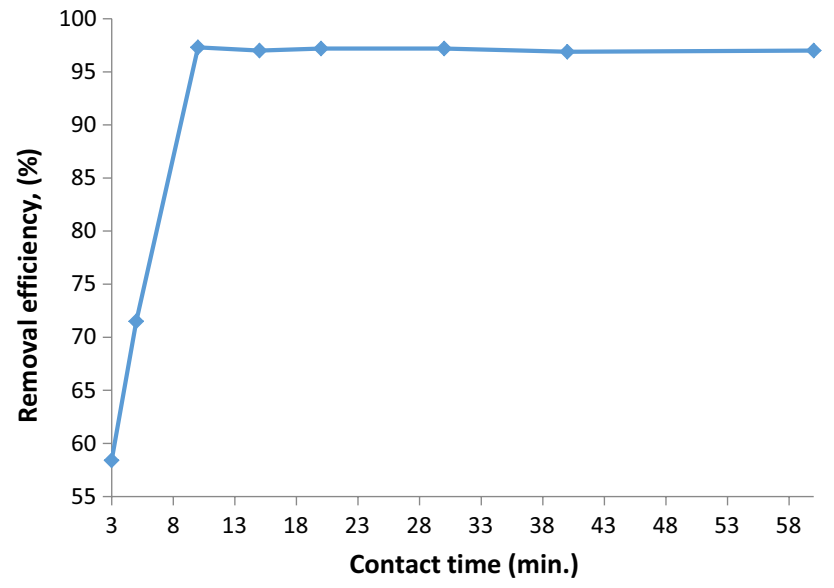

Fig. 4 Effect of contact time on As(III) removal onto the used filter cigarette ash surface

\section{Effect of initial pH on As(III) adsorption}

As shown in Fig. 5, pH variations are effective on As(III) uptake because it determines the type of arsenic ion species and the electrical charge of the adsorbent surface. $\mathrm{pH}_{\mathrm{zpc}}$ plays an important role in the adsorption process and affects not only the adsorbent surface load, but also the degree of ionization of the materials in the solution (Sigdel et al. 2016). As shown in Fig. 5, the general observation is that as $\mathrm{pH}$ increases, As(III) adsorption increases until $\mathrm{pH}=6-7$. Subsequently, as the $\mathrm{pH}$ increases, the amount of As(III) adsorption decreases. The used cigarette filter ash exhibits maximum As(III) removal near neutral $\mathrm{pH}$ because of the speciation of As(III). At pHs below 8, As(III) is mainly present in solution as $\mathrm{H}_{3} \mathrm{AsO}_{3}$ and at $\mathrm{pHs}$ greater than 8 as species $\mathrm{H}_{2} \mathrm{AsO}_{3}^{-}, \mathrm{HAsO}_{3}^{2-}$ and $\mathrm{AsO}_{3}^{3-}$ (Inoue et al. 2018). Based on the findings of this study, $\mathrm{pH}_{\mathrm{zpc}}$ for used cigarette filter ash is about 8.57. At $\mathrm{pH}$ greater than $\mathrm{pH}_{\mathrm{zpc}}$, the used cigarette filter ash surface takes a negative charge and at lower $\mathrm{pH}$ takes a positive charge. Consequently, As(III) uptake

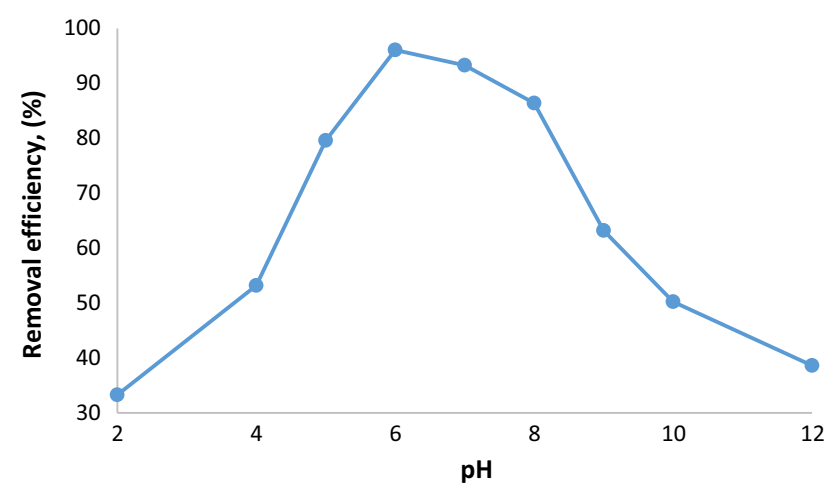

Fig. 5 Effect of $\mathrm{pH}$ on As(III) removal at different initial $\mathrm{pH}$ values onto used cigarette filter ash is not electrostatically desirable at high $\mathrm{pH}$ owing to similar charges or at very acidic conditions where As(III) and the surface of used cigarette filter ash have neutral charges. Because too much acidity was not suitable for the practical operating of water and wastewater samples, neutral solution (about $\mathrm{pH}$ 7) was chosen for additional tests.

\section{Effect of adsorbent dosage on As(III) adsorption}

As shown in Fig. 6, with the increase in the adsorbent dosage, the percentage of As(III) removal is increased until it reaches equilibrium at $0.1 \mathrm{~g}$. The reason for this increase is because as the amount of adsorbent increases, the number of sites active on the adsorbent surface can be increased. However, the decreasing trend in As(III) removal after $0.1 \mathrm{~g}$ can be attributed to the large number of free active sites participating in the adsorption due to the limited number of As(III) ions (Ngah and Hanafiah 2008; Habuda-Stanić and Nujić 2015).

\section{Effect of initial As(III) concentration}

The effect of the starting As(III) concentration on its removal was investigated by gradually increasing its concentration from 5 to $100 \mathrm{mg} / \mathrm{L}$. The change in removal efficiency percent on the initial As(III) concentrations is illustrated in Fig. 7. The findings indicated that As(III) removal rises at low starting concentrations for a special adsorption time period. It can be said that the adsorption of arsenic rapidly occurs at the initial phase of the contact time, but it gradually slows down till the equilibrium. The fast adsorption at the initial phase is likely owing to the accessibility of large surface area for adsorption. After a certain time, the residual surface sites are hard to be captured due to repulsion forces between the solute molecules of the solid and bulk phases (Bazrafshan et al. 2015). This causes longer periods to reach the equilibrium.

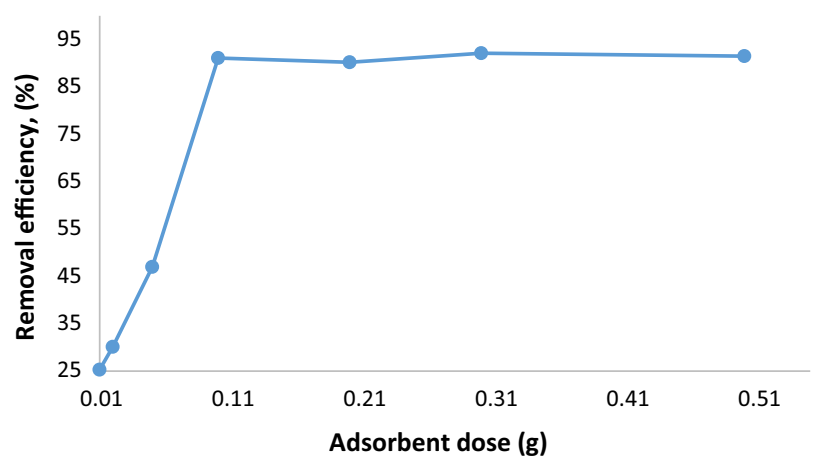

Fig. 6 Effect of adsorbent dosage on the removal percentage of As(III) 


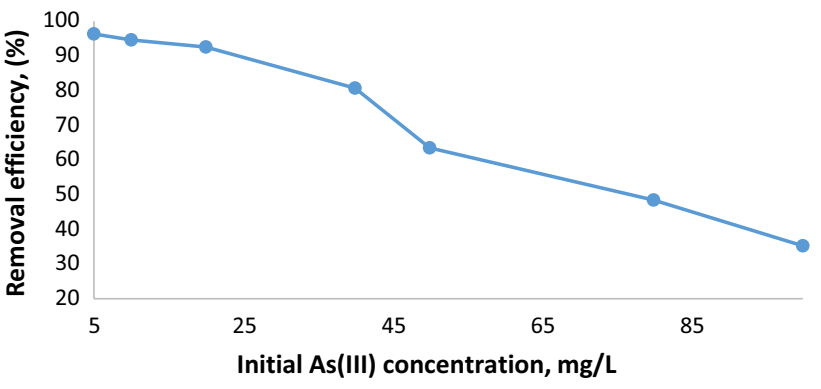

Fig. 7 Effect of initial As(III) concentration on the removal of As(III)

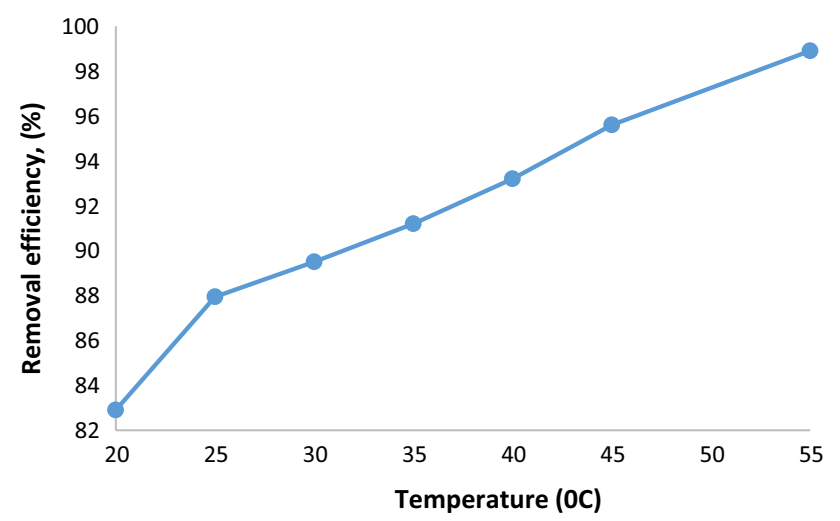

Fig. 8 Effect of temperature on the removal of As(III)

\section{Effect of temperature on the As(III) adsorption}

Figure 8 clarifies the impact of temperature on As(III) adsorption, where the adsorption efficiency enhanced linearly with an increment in temperature. To explain the reason for these results, it can be said that with increasing temperature, the mobility and the rate of As(III) ions emission on the surface of the used cigarette filter ash will increase, which will increase the removal efficiency at higher temperatures.

\section{Equilibrium modeling}

Experimental equilibrium data for the adsorption of As(III) on used cigarette filter ash have been investigated using Langmuir, Freundlich and Dubinin-Radushkevitch (D-R) isotherms. The linear equations for these isotherms are given in Table 2.

\section{Linear fitness of isotherm models}

Linear diagrams of Langmuir, Freundlich and Dubinin-Radushkevitch isotherms are displayed in Figures S1, S2 and S3, respectively. The isotherm variables for each model are determined from the corresponding graphs and briefed in Table 3 . Additionally, the separation factor, $R_{\mathrm{L}}$, is also calculated for the Langmuir model and is defined as follows (Kazi et al. 2018):

$R_{\mathrm{L}}=\frac{1}{1+K_{\mathrm{L}} C_{0}}$,
Table 2 Linear equations of isotherm models

\begin{tabular}{llll}
\hline Isotherm model & Linear form & Plot & References \\
\hline Langmuir & $\frac{1}{q_{\mathrm{e}}}=\frac{1}{K_{\mathrm{L}} q_{\mathrm{m}}} \frac{1}{C_{\mathrm{e}}}+\frac{1}{q_{\mathrm{m}}}$ & $\frac{1}{q_{\mathrm{e}}} \mathrm{vs} \frac{1}{C_{\mathrm{e}}}$ & Ardejani et al. (2008) \\
Freundlich & $\log q_{\mathrm{e}}=\log K_{\mathrm{F}}+\frac{1}{n} \log C_{\mathrm{e}}$ & $\log q_{\mathrm{e}}$ vs $\log C_{\mathrm{e}}$ & Kerkez and Bayazit (2014) \\
Dubinin-Radushkevitch & $\ln q_{\mathrm{e}}=\ln q_{\mathrm{m}}-\beta \varepsilon^{2}$ & $\ln q_{\mathrm{e}}$ vs $\varepsilon^{2}$ & Kazi et al. (2018) \\
\hline
\end{tabular}

$q_{\mathrm{e}}$ : experimental adsorption capacity $(\mathrm{mg} / \mathrm{g}), q_{\mathrm{m}}$ : maximum adsorption capacity $(\mathrm{mg} / \mathrm{g}), C_{\mathrm{e}}$ : concentration of $\mathrm{As}(\mathrm{III})$ in the solution at equilibrium $(\mathrm{mg} / \mathrm{L}), K_{\mathrm{L}}$ : Langmuir isotherm constant $(\mathrm{L} / \mathrm{mg}), k_{\mathrm{F}} \& \frac{1}{n}$ are Freundlich isotherm constants, $\beta$ : a constant related to the mean energy of adsorption $\left(\mathrm{mol}^{2} \mathrm{~kJ}^{-2}\right)$ and $\varepsilon$ is the Polanyi potential given as: $\varepsilon=R T \ln \left(1+\frac{1}{C_{\mathrm{e}}}\right)$, where $T$ is the temperature $(\mathrm{K})$ and $R$ is the gas constant $\left(8.314 \mathrm{~J} \mathrm{~K}^{-1} \mathrm{~mol}^{-1}\right)$

Table 3 Langmuir, Freundlich and D-R isotherm constants for the adsorption of As(III) onto the used cigarette filter ash

\begin{tabular}{|c|c|c|c|}
\hline$q_{\mathrm{m}}\left(\mathrm{mg} \mathrm{g}^{-1}\right)$ & $K_{\mathrm{L}}$ & $R_{\mathrm{L}}$ & $R^{2}$ \\
\hline \multicolumn{4}{|l|}{ Langmuir } \\
\hline 33.33 & 0.90 & 0.01 & 0.991 \\
\hline$n$ & & & $R^{2}$ \\
\hline \multicolumn{4}{|l|}{ Freundlich } \\
\hline 2.99 & & & 0.893 \\
\hline$q_{\mathrm{m}}\left(\mathrm{mg} \mathrm{g}^{-1}\right)$ & $\beta\left(\mathrm{mol}^{2} \mathrm{~kJ}^{-2}\right)$ & $R^{2}$ & $\overline{E\left(\mathrm{~kJ} \mathrm{~mol}^{-1}\right)}$ \\
\hline \multicolumn{4}{|c|}{ Dubinin-Radushkevitch $(D-R)$} \\
\hline 29.42 & $9 \times 10^{-8}$ & 0.865 & 2.36 \\
\hline
\end{tabular}


where $C_{0}$ is the initial concentration of As(III) ions (mg/L) and $K_{\mathrm{L}}(\mathrm{L} / \mathrm{mg})$ is the Langmuir constant. The adsorption process is considered to be desirable if $0<R_{\mathrm{L}}<1$. Furthermore, the mean energy $E$, which is the free energy transfer of one mole of solute from infinity to the surface of the adsorbent, can be evaluated by Eq. (4):

$E=\frac{1}{\sqrt{ } 2 \beta}$

The presumptions of the Dubinin-Radushkevitch model are that the adsorption has a multilayer nature, includes van der Waals forces and is appropriate for physical adsorption processes. If $E<8 \mathrm{~kJ} \mathrm{~mol}^{-1}$, then the adsorption process might be performed physically, but if $E>8 \mathrm{~kJ} \mathrm{~mol}^{-1}$ chemical adsorption may occur (Kazi et al. 2018).

As the results show, on the basis of the values of $R^{2}$, it can be decided that experimental data are more consistent with the Langmuir isotherm model. Many researchers have confirmed the validness of the Langmuir model for the adsorption process (Sigdel et al. 2016; Chowdhury et al. 2018; Inoue et al. 2018). In accord with the Langmuir model, the maximum adsorption capacity $\left(q_{\mathrm{m}}\right)$ and Langmuir constant $\left(K_{\mathrm{L}}\right)$ for the adsorption process were calculated as $33.33 \mathrm{mg} / \mathrm{g}$ and $0.90 \mathrm{~L} / \mathrm{g}$, respectively. The calculated value for $R_{\mathrm{L}}$ is 0.01 which is indicative of the high desirability of the adsorption process $\left(0<R_{\mathrm{L}}<1\right)$. Furthermore, it is obvious that the adsorption of As(III) by the used cigarette filter ash may be illustrated as a physical adsorption process for the $E$ value of $2.63 \mathrm{~kJ}$.

Table 4 Thermodynamic parameters $\Delta G^{\circ}, \Delta H^{\circ}$ and $\Delta S^{\circ}$ of $\operatorname{As}(\mathrm{III})$ adsorbed on the used cigarette filter ash

\begin{tabular}{llll}
\hline$T(\mathrm{~K})$ & $\Delta G^{\circ}(\mathrm{KJ} / \mathrm{mol})$ & $\Delta H^{\circ}(\mathrm{kJ} / \mathrm{mol})$ & $\Delta S^{\circ}(\mathrm{kJ} / \mathrm{mol} \mathrm{K})$ \\
\hline 293 & -3.845 & 60.412 & 0.216 \\
298 & -4.925 & & \\
303 & -5.398 & & \\
308 & -5.988 & & \\
313 & -6.812 & & \\
318 & -8.139 & & \\
328 & -12.281 & & \\
\hline
\end{tabular}

\section{Thermodynamic study}

The thermodynamic variables like enthalpy $\left(\Delta H^{\circ}\right)$, free energy $\left(\Delta G^{\circ}\right)$ and entropy $\left(\Delta S^{\circ}\right)$ variations and also activation energy $\left(E_{\mathrm{a}}\right)$ are parameters that control the spontaneity of an adsorption process. A process is spontaneous if its $\Delta G^{\circ}$ decreases with increasing temperature (Ngah and Hanafiah 2008). The temperatures used in this thermodynamic study were 293, 298, 303, 308, 313, 318 and $328 \mathrm{~K}$. The impact of temperature on the As(III) uptake on the used cigarette filter ash was investigated, and it was found that the amount of adsorption increased with rising temperature. The discussed thermodynamic parameters are calculated using the following equations:

$\ln \left(K_{\mathrm{d}}\right)=\ln \left(\frac{q_{\mathrm{e}}}{C_{\mathrm{e}}}\right)=\frac{-\Delta G^{0}}{R T}$

$\ln \left(K_{\mathrm{d}}\right)=\frac{\Delta S^{0}}{R}-\frac{\Delta H^{0}}{R T}$

$\Delta G^{0}=\Delta H^{0}-T \Delta S^{0}$

where $K_{\mathrm{d}}$ is the equilibrium constant, $q_{\mathrm{e}}$ is the equilibrium adsorption capacity of $\mathrm{As}(\mathrm{III})(\mathrm{mg} / \mathrm{g}), C_{\mathrm{e}}$ is the equilibrium As(III) concentration in the solution $(\mathrm{mg} / \mathrm{L}), T$ is the solution temperature $(\mathrm{K})$ and $R$ is the gas constant $(8.314 \mathrm{~J} /$ mol K). The outcomes are presented in Table 4. Positive enthalpy change $\left(\Delta H^{\circ}\right)$ proves that the process is an endothermic type and the adsorption value consolidates the formation of partial chemical processes that exist throughout the adsorption process (Kumar et al. 2013). The negative value of free energy change $\left(\Delta G^{\circ}\right)$ points out that the uptake process is spontaneous. The reduction in $\Delta G^{\circ}$ value with rising temperature also indicates the spontaneous character of the As(III) adsorption process (Zou et al. 2011). Liu and co-workers reported that As(III) adsorption by magnetite nanoparticles is endothermic and has a spontaneous nature (Liu et al. 2015). The entropy change $\left(\Delta S^{\circ}\right)$ is also positive; this proves that during the adsorption process, there is randomness at the interface of the fluid/solid.

The adsorption capacity is a great significance variable that implies the behavior of an adsorbent. Table 5 compares
Table 5 Maximum adsorption capacity of different adsorbents for As(III) removal

\begin{tabular}{lll}
\hline Adsorbents & $q_{\mathrm{m}}(\mathrm{mg} / \mathrm{g})$ & References \\
\hline$\alpha-\mathrm{Fe}_{2} \mathrm{O}_{3}$ & 95 & Tang et al. (2011) \\
Hydrous iron oxide-impregnated alginate beads & 47.80 & Sigdel et al. (2016) \\
$\mathrm{La}_{2} \mathrm{O}_{3}$-sawdust & 22.03 & Setyono and Valiyaveettil (2014) \\
Surfactant-modified montmorillonite & 1.48 & Soleimani et al. (2018) \\
Magnetic pine cone biomass & 18.02 & Pholosi et al. (2019) \\
Hydroxyapatite-bentonite clay-nanocrystalline cellulose & 51.01 & Hokkanen et al. (2019) \\
Used cigarette filter ash & 33.33 & This study \\
\hline
\end{tabular}


the highest adsorption capacity of the used cigarette filter ash with other reported adsorbents for the case of adsorbing As(III).

\section{Conclusion}

Nowadays, it is very important to remove heavy metals such as arsenic from the water because of their toxicity. One of the methods of removing such metals is the use of used cigarette filter ash, which is very effective because of its easy preparation, rapid reaction time and environmental cleanup due to its collection and removal. In this research was prepared used cigarette filter ash as a new adsorbent for the removal of As(III) from aqueous solutions. The adsorbent structure was identified and analyzed by SEM, EDX and BET methods. The examining of the results of the study showed that the amount of arsenic uptake was dependent on the $\mathrm{pH}$ of the solution and the highest removal percent was obtained in the range of $\mathrm{pH} 6-7$. Experimental data were fitted with various models of isotherm. Comparing the values of $\mathrm{R}^{2}$, the Langmuir isotherm model was chosen as the best isotherm model for describing the adsorption of As(III). The maximum adsorption capacity was calculated as $33.33 \mathrm{mg} / \mathrm{g}$ based on the Langmuir model. The calculated thermodynamic variables indicated that the uptake process is spontaneous and endothermic. Therefore, the used cigarette filter ash adsorbent provides a cost-effective and efficient way to eliminate As(III) from water.

Acknowledgements The authors appreciate the Islamic Azad University, Bandar Abbas Branch, for the financial assistance of the present research

\section{Compliance with ethical standards}

Conflict of interest The authors declare that they have no conflict of interest.

Open Access This article is distributed under the terms of the Creative Commons Attribution 4.0 International License (http://creativeco mmons.org/licenses/by/4.0/), which permits unrestricted use, distribution, and reproduction in any medium, provided you give appropriate credit to the original author(s) and the source, provide a link to the Creative Commons license, and indicate if changes were made.

\section{References}

Ardejani FD, Badii K, Limaee NY, Shafaei SZ, Mirhabibi A (2008) Adsorption of Direct Red 80 dye from aqueous solution onto almond shells: effect of $\mathrm{pH}$, initial concentration and shell type. $\mathrm{J}$ Hazard Mater 151(2-3):730-737

Barnes RL (2011) Regulating the disposal of cigarette butts as toxic hazardous waste. Tob Control 20(Suppl 1):i45-i48
Bazrafshan E, Kord Mostafapour F, Rahdar S, Mahvi AH (2015) Equilibrium and thermodynamics studies for decolorization of Reactive Black 5 (RB5) by adsorption onto MWCNTs. Desalin Water Treat 54(8):2241-2251

Bhowmick S, Chakraborty S, Mondal P, Van Renterghem W, Van den Berghe S, Roman-Ross G, Chatterjee D, Iglesias M (2014) Montmorillonite-supported nanoscale zero-valent iron for removal of arsenic from aqueous solution: kinetics and mechanism. Chem Eng J 243:14-23

Chowdhury T, Zhang L, Zhang J, Aggarwal S (2018) Removal of arsenic (III) from aqueous solution using metal organic frameworkgraphene oxide nanocomposite. Nanomaterials 8(12): 1062

Habuda-Stanić M, Nujić M (2015) Arsenic removal by nanoparticles: a review. Environ Sci Pollut Res 22(11):8094-8123

Haddabi MA, Ahmed M, Jebri ZA, Vuthaluru H, Znad H, Kindi MA (2016) Boron removal from seawater using date palm (Phoenix dactylifera) seed ash. Desalin Water Treat 57(11):5130-5137

Hokkanen S, Doshi B, Srivastava V, Puro L, Koivula R (2019) Arsenic (III) removal from water by hydroxyapatite-bentonite claynanocrystalline cellulose. Environ Prog Sustain Energy. https:// doi.org/10.1002/ep.13147

Huang P, Ye Z, Xie W, Chen Q, Li J, Xu Z, Yao M (2013) Rapid magnetic removal of aqueous heavy metals and their relevant mechanisms using nanoscale zero valent iron (nZVI) particles. Water Res 47(12):4050-4058

Inoue K, Harada H, Ghimire KN, Biswas BK, Kawakita H, Ohto K (2018) Environmentally benign adsorption materials for removing arsenic from aquatic environment. Adv Mater Phys Chem 8(01):51

Kazi TG, Brahman KD, Baig JA, Afridi HI (2018) A new efficient indigenous material for simultaneous removal of fluoride and inorganic arsenic species from groundwater. J Hazard Mater 357:159-167

Kerkez Ö, Bayazit ŞS (2014) Magnetite decorated multi-walled carbon nanotubes for removal of toxic dyes from aqueous solutions. $\mathrm{J}$ Nanopart Res 16(6):2431

Kumar M, Tamilarasan R, Sivakumar V (2013) Adsorption of Victoria blue by carbon/Ba/alginate beads: kinetics, thermodynamics and isotherm studies. Carbohydr Polym 98(1):505-513

Lee M, Kim GP, Song HD, Park S, Yi J (2014) Preparation of energy storage material derived from a used cigarette filter for a supercapacitor electrode. Nanotechnology 25(34):345601

Li YF, Wang D, Li B, Dong L, Sun G (2019) Development of arsenic removal technology from drinking water in developing countries. Arsenic Contamination in Asia. Springer, Berlin, pp 163-179

Liu CH, Chuang YH, Chen TY, Tian Y, Li H, Wang MK, Zhang W (2015) Mechanism of arsenic adsorption on magnetite nanoparticles from water: thermodynamic and spectroscopic studies. Environ Sci Technol 49(13):7726-7734

Mishra S et al (2019) Heavy metal contamination: an alarming threat to environment and human health. In: Sobti R, Arora N, Kothari R (eds) Environmental biotechnology: for sustainable future. Springer, Singapore. https://doi. org/10.1007/978-981-10-7284-0_5

Moayedi H, Aghel B, Abdullahi MAM, Nguyen H, Rashid ASA (2019) Applications of rice husk ash as green and sustainable biomass. J Clean Prod 237:117851

Ngah WW, Hanafiah M (2008) Adsorption of copper on rubber (Hevea brasiliensis) leaf powder: kinetic, equilibrium and thermodynamic studies. Biochem Eng J 39(3):521-530

Novotny TE, Lum K, Smith E, Wang V, Barnes R (2009) Filtered cigarettes and the case for an environmental policy on cigarette waste. Int J Environ Res Public Health 6:1691-1705

Pholosi A, Naidoo EB, Ofomaja AE (2019) Enhanced Arsenic (III) adsorption from aqueous solution by magnetic pine cone biomass. Mater Chem Phys 222:20-30

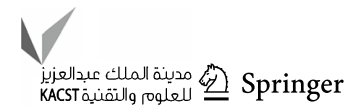


Rahmani A, Ghafari HR, Samadi MT, Zarabi M (2011) Synthesis of zero valent iron nanoparticles (nzvi) and its efficiency in arsenic removal from aqueous solutions. Water Wastewater 1:35-41

Setyono D, Valiyaveettil S (2014) Chemically modified sawdust as renewable adsorbent for arsenic removal from water. ACS Sustain Chem Eng 2(12):2722-2729

Sigdel A, Park J, Kwak H, Park PK (2016) Arsenic removal from aqueous solutions by adsorption onto hydrous iron oxide-impregnated alginate beads. J Indust Eng Chem 35:277-286

Smith EA, Novotny TE (2011) Whose butt is it? Tobacco industry research about smokers and cigarette butt waste. Tob Control 20(Suppl 1):i2-i9

Smith N, Lawson J, Khangura A, Johnson B (2015) Cigarette disposal investigation and assessment. https://doi.org/10.14288/1.0108867

Soleimani S, Azarian G, Moattar F, Karbassi A, Godini K, Niknam E (2018) Application of surfactant-modified montmorillonite for As(III) removal from aqueous solutions: kinetics and isotherm study. Desalin Water Treat 115:236-248

Soltani SM, Yazdi SK, Hosseini S (2014) Effects of pyrolysis conditions on the porous structure construction of mesoporous charred carbon from used cigarette filters. Appl Nanosci 4(5):551-569

Song W, Zhang M, Liang J, Han G (2015) Removal of As (V) from wastewater by chemically modified biomass. J Mol Liq 206:262-267
Tang W, Li Q, Li C, Gao S, Shang JK (2011) Ultrafine $\alpha-\mathrm{Fe}_{2} \mathrm{O}_{3}$ nanoparticles grown in confinement of in situ self-formed "cage" and their superior adsorption performance on arsenic (III). J Nanopar Res 13(6):2641-2651

Vázquez-Rivera NI, Soto-Pérez L, St John JN, Molina-Bas OI, Hwang SS (2015) Optimization of pervious concrete containing fly ash and iron oxide nanoparticles and its application for phosphorus removal. Constr Build Mater 93:22-28

Wang XS, Lu ZP, Miao HH, He W, Shen HL (2011) Kinetics of Pb(II) adsorption on black carbon derived from wheat residue. Chem Eng J 166(3):986-993

Zou W, Li K, Bai H, Shi X, Han R (2011) Enhanced cationic dyes removal from aqueous solution by oxalic acid modified rice husk. J Chem Eng Data 56(5):1882-1891

Publisher's Note Springer Nature remains neutral with regard to jurisdictional claims in published maps and institutional affiliations. 